\title{
$\begin{array}{lllllllllllll}\mathbf{S} & \mathbf{P} & \mathbf{R} & \mathbf{A} & \mathbf{W} & \mathbf{O} & \mathbf{Z} & \mathbf{A} & \mathbf{D} & \mathbf{A} & \mathbf{N} & \mathbf{I} & \mathbf{E}\end{array}$
}

Ius Matrimoniale

28 (2017) $\mathrm{nr} 3$

DOI:10.21697/im.2017.28.3.07

\section{Ogólnopolskie Forum Sądowe (Gródek nad Dunajcem: 12-13 VI 2017 roku)}

W dniach 12 i 13 czerwca 2017 r. odbyło się w Gródku n. Dunajcem w ośrodku rekolekcyjnym Diecezji Tarnowskiej „Arka”, pod patronatem naukowym Rady Prawnej Konferencji Episkopatu Polski, VIII Ogólnopolskie Forum Sądowe - „Reforma procesowa papieża Franciszka - pierwsze doświadczenia”.

$\mathrm{Na}$ zaproszeniu na powyższą konferencję naukową - w której uczestniczyło ponad 130 osób z Czech, Polski, Stanów Zjednoczonych oraz Ukrainy - zostały przypomniane słowa św. Jana Pawła II z jego ostatniej alokucji rotalnej z dnia 29 stycznia 2005 roku, które również dzisiaj pozostają wymowne, przede wszystkim, w kontekście reformy procesowej papieża Franciszka z roku 2015: „jest prawdą, że sprawiedliwość wymierzana sprawnie pozostaje konkretną służbą prawdzie i tworzy prawo osoby. Niemniej jednak, fałszywa szybkość, która jest ze szkodą dla prawdy, pozostaje jeszcze bardziej niesprawiedliwa”.

Gościem konferencji był ks. prof. dr Grzegorz Erlebach, prałat audytor Trybunału Apostolskiego Roty Rzymskiej, natomiast okolicznościowe pisemne pozdrowienia uczestnikom spotkania przesłali kardynał Stanisław Dziwisz, abp Marek Jędraszewski - metropolita krakowski, abp Wiktor Skworc - metropolita katowicki oraz bp Artur G. Miziński - sekretarz generalny Konferencji Episkopatu Polski. Warto także podkreślić czynne uczestnictwo w spotkaniu p. mgra Mikołaja Pawlaka, dyrektora departamentu ds. rodzinnych i nieletnich w Ministerstwie Sprawiedliwości, który reprezentował Ministra Sprawiedliwości. 
Słowo wprowadzające do uczestników konferencji wygłosił bp dr Ryszard Kasyna, biskup pelpliński oraz przewodniczący Rady Prawnej Konferencji Episkopatu Polski a także sędzia Najwyższego Trybunału Sygnatury Apostolskiej. Sesjom naukowym forum w pierwszym dniu przewodniczył ks. dr hab. Piotr Steczkowski, prof. UR, natomiast w drugim dniu ks. dr Ryszard Biernat.

Ponadto w czasie konferencji odbyły się spotkania oficjałów, obrońców węzła małżeńskiego oraz adwokatów kościelnych, którym odpowiednio przewodniczyli ks. dr hab. Leszek Adamowicz, prof. KUL, p. dr Aleksandra Brzemia-Bonarek z Uniwersytetu Papieskiego Jana Pawła II w Krakowie oraz ks. prof. dr hab. Ryszard Sztychmiler z Uniwersytetu Warmińsko-Mazurskiego.

Natomiast uroczystej porannej koncelebrowanej Mszy św. na początku drugiego dnia konferencji przewodniczył bp Leszek Leszkiewicz - biskup pomocniczy diecezji tarnowskiej, podczas której okolicznościową homilię wygłosił wieloletni oficjał Sądu Biskupiego w Tarnowie ks. infułat dr Władysław Kostrzewa - obchodzący złoty jubileusz kapłaństwa.

W czasie ósmego forum sądowego zostały wygłoszone następujące referaty:

- „Niektóre aspekty apelacji w procesie zwyczajnym o nieważność małżeństwa w świetle m. p. Mitis Iudex Dominus Iesus" (ks. prałat prof. dr Grzegorz Erlebach),

- „Możliwość pozyskania dokumentów cywilnych dla kościelnych procesów małżeńskich" (mgr Mikołaj Pawlak),

- „Okoliczności uzasadniające proces małżeński przed biskupem: brak wiary, krótki czas pożycia małżeńskiego, aborcja, pozostawanie w relacji pozamałżeńskiej (MIDI, art. $14 \$ 1$ )” (ks. prof. dr hab. H. Stawniak, UKSW),

- „Okoliczności uzasadniające proces małżeński przed biskupem: podstępne zatajenie bezpłodności, poważnej choroby zakaźnej, potomstwa z wcześniejszego związku lub pozbawienia wolności; zawarcie małżeństwa z przyczyny całkowicie obcej życiu małżeńskiemu lub wynikającej z nieoczekiwanej ciąży kobiety; użycie przemocy fizycznej w celu wymuszenia 
konsensu; brak używania rozumu potwierdzony dokumentacją medyczną (MIDI, art. 14 \$2)” (ks. dr hab. Piotr Majer, prof. UPJPII),

- „Dynamiczna posługa adwokata w zreformowanym procesie małżeńskim" (ks. prof. dr hab. Ryszard Sztychmiler, UWM),

- „Dynamiczna posługa obrońcy węzła w zreformowanym procesie małżeńskim" (dr Adam Bartczak, UŁ),

- „Badanie przedprocesowe (czyli duszpasterskie) - rola i znaczenie dla sprawnego procesu małżeńskiego (MIDI, art. 2-5)” (dr hab. Marta Greszata-Telusiewicz, prof. KUL),

- „Dowód z nowych technologii komunikacji w procesie małżeńskim” (ks. prof. dr hab. Tomasz Rozkrut, UPJPII).

Zarówno w pierwszym jak i drugim dniu sympozjum, wokół problematyki ww. referatów, wywiązała się interesująca dyskusja, ponadto wielu pracowników sądownictwa kościelnego, korzystając z obecności ks. prałata Grzegorza Erlebacha, odbyło z nim szereg ważnych oraz praktycznych konsultacji.

Materiały z konferencji, podobnie jak z poprzednich sądowych spotkań w Gródku nad Dunajcem, zostaną wydane przez „Biblos” Wydawnictwo Diecezji Tarnowskiej. 